\title{
The knowledge and Professional Attitudes Toward Denture Adhesives in Mosul
}

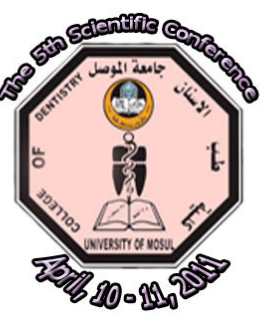

\section{ABSTRUCT}

Aims: The aims of the present study is evaluate the dentist knowledge and believes toward denture adhesive through generation of discussion among dentist (in ministry of health and ministry of higher education) in Mosul city. Materials and Methods: In a dental meeting that held on April 2009 in College of Dentistry ,university of Mosul ,a questionnaire paper was given to 264 dentist which consist of two: part the first one evaluate dentist knowledge about denture adhesive, the second one evaluate the dentist attitude toward denture adhesive. Result: The findings of the present study showed that $(9.8 \%, 67.8 \%$ and $22.4 \%)$ of dentists had respectively weak, moderate and good knowledge toward denture adhesive while $3.1 \%, 80.4 \%$ and $16.6 \%$ ) had respectively negative, moderate and positive attitude toward denture adhesive materials. The $\chi 2$ test showed non significant statistical relation between dentist knowledge about denture adhesives and their previous years of experience, place of work, sex and their degree of education. Statistical analysis methods used to analyze and asses the result of this study were SPSS version 13.0. Conclusions: The findings of the present study showed that dentist knowledge and attitude toward denture adhesive materials was moderate. Their information about denture adhesive indications, contraindications, advantages and disadvantages were very poor therefore prosthodontic specialist in College of Dentistry, University of Mosul should insist on denture adhesive in student's curriculum with increasing the credit hours.

\section{الخلاصة}

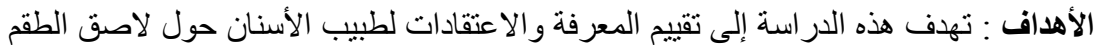

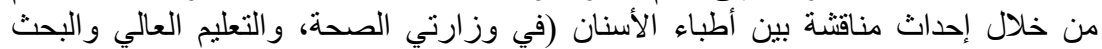

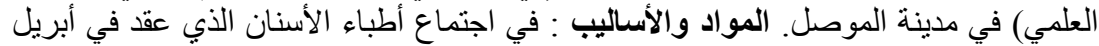

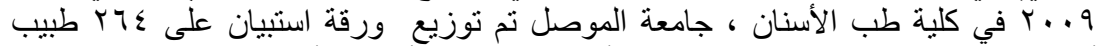

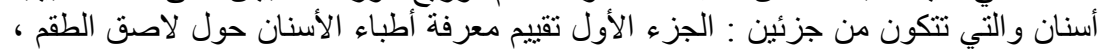

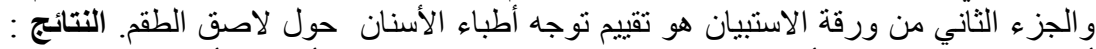

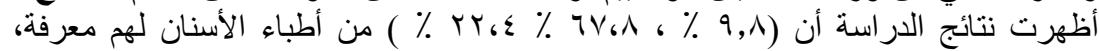

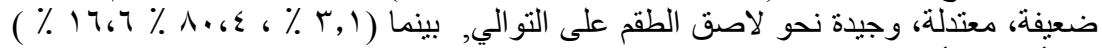

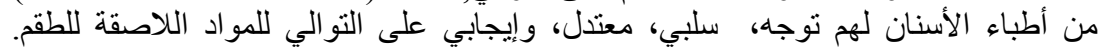

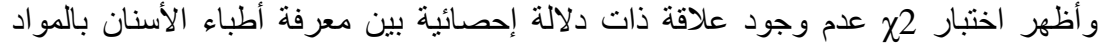

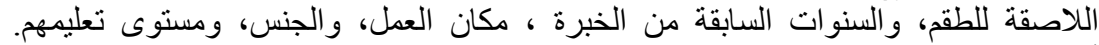
أساليب التحليل الإحصائية الدستخدمة في تحليل وتقويم نتائج هذه الدراسة إحصائيا هو $11 \% 6$. نسخة

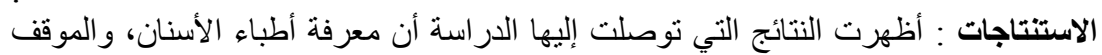

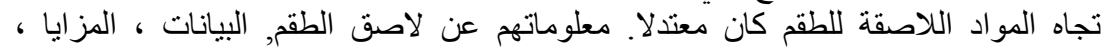

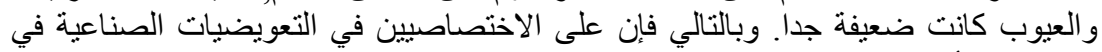
كلية طب الأسنان ، جامعة الموصل، الإصر ار على تدريس المو اد اللاصقة للطقم في المناهج
Prof Nadira A Hatim (BDS,MSc); $\quad$ Asst Lect Hala K Ali (BDS, MSc); Asst Lect Hydar M Shindala (BDS, MSc)
Department of Prosthodontics and department of Pedodontics, Orthodontics and Preventive Dentistry, Dentistry College, Mosul University

Key Words: knowledge, attitude, denture adhesive material. 
Q) enture adhesive materials are widely used by many patients to improve the retention, stability and masticatory efficiency of their prosthesis ${ }^{(1-5)}$. Therefore, dentists need to know about denture adhesives to educate all denture patients about the advantages, disadvantages and uses of the product, and to identify those patients for whom such a product is advisable and/or necessary for a satisfactory denture-wearing experience ${ }^{(6)}$.

Dental professionals have been slow to accept denture adhesives as a means to enhance denture retention, stability and function. Despite considerable documentation advocating patient's use of adhesives, many dentists view adhesive usage as a poor reflection of their clinical skills and prosthetic expertise ${ }^{(7)}$.

A growing body of supporting literature over the past 20 years is changing this view. Practitioners are beginning to accept that fixatives are a useful adjusts to denture therapy ${ }^{(8)}$.

Many studies have been carried out to evaluate patients and dentist knowledge and attitude toward denture adhesive in America ${ }^{(9)}$,Australia ${ }^{(10)}$, Turkey ${ }^{(11,12)}$ and Iran $^{(13)}$. Therefore this study was conducted to evaluate the dentist knowledge and believes toward denture adhesive through generation of discussion among dentist in Ministry of health and Ministry of higher education in Mosul city.

\section{MATERIALS AND METHODS}

In a dental meeting that held on April 2009 in College of Dentistry, University of Mosul. A questionnaire papers was given to 264 dentist, 80 questionnaire papers were excluded because some questions were not answered completely so, only 183 questionnaire papers were included in this study.

The questionnaires were based on previously conducted study of (Sloughter et al) ${ }^{(9)}$, ( Koksal et al. $)^{(12)}$ and (Fakhri et al) ${ }^{(13)}$ with some modifications.

The questionnaire include two parts, the first part evaluate the degree of knowledge of dentist in which the dentist knowledge was classified into (weak, moderate and good) according to their score(1-4,5-8 and 9-12)respectively each correct answer was given a score of +1 .Questions in the first part were as follows:

\section{Questionnaire of Part one:}

Note: please answer all questions.

Male $\square$ Female $\square$

When did you receive your BDS, MSc, $\mathrm{PhD}$,diploma degree?

BDS degree? Year

MSc, PhD ,diploma degree?_Year

Where did you work? Ministry of health $\square$

(I) Questions regarding knowledge:

Ministry of higher education $\square$

(A). select the most suitable answer from the following:

1. Denture adhesives:

a. Could fix up broken acrylic bases $\square$

b. Increase the strength of acryl during laboratory processes

of denture preparation $\square$

c. Increase retention and stability of dentures. $\square$

2. Denture adhesives are:

a. Home re-liner kits $\square$

b. Tissue conditioners $\square$

c. None of the above

Journal of the $5^{\text {th }}$ Scientific Conference of Dentistry College, Apr. 2011 
3. Which of the following statements is true?

a. Most denture adhesives are soluble in water $\square$

b. Most denture adhesives are insoluble in water $\square$

4. Which of the following is applied to increase cohesion of denture adhesives?

a. Carboxyl Methyl Cellulose $\square$

b. Hexachlorophene口

c. Oil $\square$

d. No opinion $\square$

5. Denture adhesives are able to increase the retention of denture by:

a. Increasing the viscosity and eliminating the spaces between denture and oral mucosa $\square$

b. Decreasing the viscosity and eliminating the spaces between denture and oral mucosa

6. Denture adhesives are available as
a. Powder $\square$
b. Paste $\square$
c. paper sheets $\square$
d. all of the above $\square$

7. Which type of denture adhesive has more durable effects?
a. Powder $\square$
b. Paste $\square$

8. Which of the following statements concerning using denture adhesives in denture of maxilla is not true?

a. Putting small pieces of paste in all mucosal surfaces of denture with $5 \mathrm{~mm}$ space from each other

b. Spreading powder in incisors and molars' areas of mucosal surfaces of denture $\square$

(B)Denture adhesives are recommended for use in:

9. Uncontrollable muscular dislodgment of movements of

Tongue, lips and cheeks. Yes $\square \quad$ No $\square$

10. Dentures with insufficient fitness and poor structure.

Yes $\square \quad$ No $\square$

11. Patients who do not want to attend recalling sessions for a

long time. $\quad$ Yes $\square \quad$ No $\square$

12. Patients suffering dry mouth (Xerostomia) due to side-effects

of the drugs or record of radiotherapy. $\quad$ Yes $\square \quad$ No $\square$

The second part of the questionnaire evaluate the degree of attitude of dentists toward denture adhesive in which statements that mentioned negative views toward denture adhesive were scored in as the following (Disagreement $=+2$, Agreement $=0$, No Opinion $=+1$.), while statements that mentioned positive views toward denture adhesive responses were scored in a reverse manner (Agreement $=+2$, Disagreement $=0$, No Opinion $=+1$.) the dentists attitude was classified as (positive, moderate and negative) according to their score (0-11,12-23-24-32) respectively. Only the moderate and good knowledge groups were included for evaluation of dentist's attitude. Questions in the second part were as follows: 
Questionnaire of Part two:

\begin{tabular}{|c|c|c|c|}
\hline Denture adhesives can cause: & agree & Disagree & No opinion \\
\hline Ieukoplakia & & $*$ & \\
\hline Oral cancer & & $*$ & \\
\hline Candidacies & $*$ & & \\
\hline Denture stomatitis & $*$ & & \\
\hline Alveolar bone resorption & & $*$ & \\
\hline Imbalance in oral flora & $*$ & & \\
\hline
\end{tabular}

: Means the correct answer

\section{Questions}

DA Increase the fitness (retention and stability)

DA Provide psychological comfort for patients

DA Mask all underlying denture problems

DA Contribute to avoiding dental visits

DA Stabilize trial bases in early stages of dental fabrication

DA Augment retention, function and comfort during interim Period after insertion of new denture.

DA Provide additional retention and stability for patients who have inadequate oral anatomy

Patient education on DA should be routine for all denture patients.

Students should be competent in management of routine denture patient.

Education on DA should be dealt in depth in Undergraduate curriculum in dental universities

DA: denture adhesive *: Means the correct answer

Statistical analysis methods used to analyze and asses the result of this study were SPSS version 13.0, percentage, frequency and $\mathrm{X}^{2}$ test.

\section{RESULTS AND DISCUSSIONS}

The results of the first part which related to the degree of knowledge of dentist were listed in Table(1) the higher degree of knowledge of dentist toward denture adhesive was moderate which is similar to that obtained by Fakhri et al ${ }^{(13)}$ in Tehran.

Table (1): Percentage of degree of knowledge of dentist

\begin{tabular}{cc} 
Degree of knowledge & Percentage \\
Week & $9.8 \%(18)$ \\
moderate & $67.8 \%(124)$ \\
good & $22.4 \%(41)$ \\
\hline
\end{tabular}

Journal of the $5^{\text {th }}$ Scientific Conference of Dentistry College, Apr. 2011 
Tables (2, 3, 4 and 5) demonstrates the relation $\left(\mathrm{X}^{2}\right.$ test)between dentist knowledge about denture adhesives and their sex, place of work, their degree of education and previous years of experience which was founded to be non significant.

Table (2): Frequency and $\mathrm{X}^{2}$ between gender and degree of knowledge.

\begin{tabular}{lllll} 
& & Gender & Total \\
Quality & Male & Female & \\
& Good & 19 & 22 & 41 \\
& Moderate & 61 & 63 & 124 \\
& Weak & 13 & 5 & 18 \\
\hline \multirow{2}{*}{ Total } & & 93 & 90 & 183 \\
PCS & & $\mathrm{X}^{2}=3.759, \mathrm{df}=2, \mathrm{P}=0.153 \mathrm{~ns}$ \\
\hline
\end{tabular}

Table (3): Frequency and $X^{2}$ between Job situation and degree of knowledge.

\begin{tabular}{lllll} 
& \multicolumn{3}{c}{ Job Situation } \\
Higher \\
Quality & Education & Health & Total \\
& Good & 19 & 22 & 41 \\
& Moderate & 52 & 72 & 124 \\
Total & Weak & 6 & 12 & 18 \\
PCS & & 77 & 106 & 183 \\
\hline
\end{tabular}

Table 4: Frequency and $\mathrm{X}^{2}$ between degree of graduation and degree of knowledge.

\begin{tabular}{llllll} 
& & Degree & & Total \\
Quality & Good & Bechalor & Master & $\mathrm{PhD}$ & \\
& Moderate & 75 & 17 & 1 & 41 \\
& Weak & 7 & 48 & 1 & 124 \\
Total & & 105 & 11 & 0 & 18 \\
PCS & & $\mathrm{X}^{2}=4.162, \mathrm{df}=4, \mathrm{P}=0.385 \mathrm{~ns}$ & 183 \\
\hline
\end{tabular}

Table (5): X2 relation between dentist knowledge and previous years of experience

\begin{tabular}{|c|c|c|c|c|c|c|c|c|c|}
\hline \multirow{4}{*}{ Quality } & \multirow[b]{3}{*}{ Good } & \multicolumn{7}{|c|}{ New Date } & \multirow[t]{2}{*}{ Total } \\
\hline & & 1 & 2 & 3 & 4 & 5 & 6 & 7 & \\
\hline & & $\begin{array}{l}1 \\
4\end{array}$ & 9 & 5 & 7 & 3 & 0 & 3 & 41 \\
\hline & Moderate & $\begin{array}{l}3 \\
9\end{array}$ & 31 & 22 & 18 & 6 & 2 & 6 & 124 \\
\hline \multirow[b]{2}{*}{ Total } & Weak & 3 & 5 & 3 & 3 & 2 & 0 & 2 & 18 \\
\hline & & $\begin{array}{l}5 \\
6\end{array}$ & 45 & 30 & 28 & 11 & 2 & 11 & 183 \\
\hline PCS & & & & $2=5$ & $\mathrm{df}=$ & $2, \mathrm{P}=$ & 936 & & \\
\hline
\end{tabular}


Table (6) showed distribution of dentist answer for each question in which $96 \%$ of them agree with the statement (using denture adhesive to increase retention and stability)which is true and came in line with the findings of many researchers ${ }^{(14-20)}$.

Table (6) showed that dentists knowledge was weak about denture adhesive solubility, composition and forms according to their answer on question number(3,4 and 6) about (57.4\%) stated that most denture adhesive are insoluble in water while denture adhesive are soluble in water due to their component because most denture adhesive are consist of material responsible for the adhesive properties which are soluble in water either partly of totally such as: Karaya gum, tragonth, acacia, pectin and gelatin ${ }^{(21-24)}$. Also (13.1\%) have no idea about the composition of methylcellulose, hydroxymethylcellulose, sodium carboxymethylcellulose denture adhesive while $(0 \%)$ have never heard about the presence of denture adhesive in form of paper sheets.

Table (6) also showed that (84.2\%) agree on statement (denture adhesive in past form has more durable effect )which is true and can be explained by the fact that Powder formulations, as a rule, do not confer the same degree of "hold" nor do their effects last as long, in comparison to comparable cream formulations, the cream adhesive when applied, spread laterally excluding air and saliva from the tissue surface of the denture, the increase of viscosity of the cream layer, compared with that of saliva is a factor for the increased retention ${ }^{(6,22)}$.

Table (6): Percentage of dentist opinion about denture adhesive

\begin{tabular}{llllll} 
Question & $\mathrm{A}$ & $\mathrm{B}$ & $\mathrm{C}$ & $\mathrm{d}$ & Total \\
Q1 & $2.7 \%(5)$ & $0.6 \%(1)$ & $96.7 \%(177)$ & $* * *$ & 183 \\
Q2 & $40.4 \%(74)$ & $24.6 \%(45)$ & $35 \%(64)$ & $* * *$ & 183 \\
Q3 & $42.6 \%(78)$ & $57.4 \%(105)$ & $* * *$ & $* * *$ & 183 \\
Q4 & $53.6 \%(98)$ & $19.1 \%(35)$ & $14.2 \%(26)$ & $13.1 \%(24)$ & 183 \\
Q5 & $70.5 \%(129)$ & $29.5 \%(54)$ & $* * *$ & $* * *$ & 183 \\
Q6 & $9.8 \%(18)$ & $30.1 \%(55)$ & $0 \%(0)$ & $60.1 \%(110)$ & 183 \\
Q7 & $15.8 \%(29)$ & $84.2 \%(154)$ & $* * *$ & $* * *$ & 183 \\
Q8 & $55.7 \%(102)$ & $44.3 \%(81)$ & $* * *$ & $* * *$ & 183 \\
\hline
\end{tabular}

***:means no questions availability

Table (7) showed the distribution of dentists knowledge about indication and contraindication of denture adhesive in which about (49.7\%) agreed that denture adhesive are not used in patient with uncontrollable muscular movements of tongue, lips and cheeks however denture adhesives are indicated in such a case as mentioned by many authors ${ }^{(24-26)}$.

Table (7): Dentist opinion about indications of denture adhesive.

$\begin{array}{llll}\text { Question } & \text { YES } & \text { NO } & \text { Total } \\ \text { Q9 } & 50.3 \%(92) & 49.7 \%(91) & 183 \\ \text { Q10 } & 63.4 \%(116) & 36.6 \%(67) & 183 \\ \text { Q11 } & 66.1 \%(121) & 33.9 \%(62) & 183 \\ \text { Q12 } & 66.1 \%(121) & 33.9 \%(62) & 183\end{array}$

The most important finding of the present study demonstrate dentists agreement $(63.4 \%)$ on statement of (using denture adhesive in a dentures with insufficient fitness and poor structure) which revealed a very weak knowledge about the indication of denture adhesive because the danger in this action is that patients may continue to wear this ill fitting denture on account of the 
improvement in retention provided by adhesive which will lead to further bone resorption , damage to the oral mucosa and an increasing inability to maintain satisfactory oral hygiene due to continual presence of thick deposit of adhesive ${ }^{(22,24,27)}$.

The results of the second part which related to the degree of attitude of dentists were listed in Table (8) the higher degree of dentist attitude toward denture adhesive was moderate.

Table (8): Percentage of degree of dentist attitude toward denture adhesives.

$\begin{array}{cc}\text { Degree of attitude } & \text { Percentage } \\ \text { Negative } & 3 \%(5) \\ \text { Moderate } & 80.4 \%(131) \\ \text { Positive } & 16.6 \%(27)\end{array}$

Table (9) illustrated the dentists' opinion about side effect of denture adhesives in which $(22.6 \%$ and $7.3 \%)$ agreed that denture adhesive can cause Ieukoplakia ,Oral cancer respectively, while the fact that denture adhesive are save, non toxic, non irritating materials that recommended for denture wearers with extremely sensitive oral mucosa ${ }^{(28)}$. Denture adhesives could act as a soft liner and lead to prevention of strangulation of the blood supply to the oral mucosa by the pressure of a hard acrylic denture base in function ${ }^{(29)}$. In addition to that commercially available formulations are almost free of carcinogenic agents and believed to be harmless ${ }^{(6)}$.

Table (9): Percentage of dentist opinion regarding side effect of denture adhesives

\begin{tabular}{cllc} 
Denture adhesives can cause: & \multicolumn{1}{c}{ Agree } & \multicolumn{1}{c}{ Disagree } & $\begin{array}{c}\text { No } \\
\text { opinion }\end{array}$ \\
leukoplakia & $22.6 \%(37)$ & $45.1 \%(74)$ & $32.3 \%(53)$ \\
Oral cancer & $7.3 \%(12)$ & $61.6 \%(101)$ & $31.1 \%(51)$ \\
Candidacies & $72.6 \%(119)$ & $12.2 \%(20)$ & $15.2 \%(25)$ \\
Denture stomatitis & $64 \%(105)$ & $18.9 \%(31)$ & $17.1 \%(28)$ \\
Alveolar bone resorption & $15.2 \%(25)$ & $60.4 \%(99)$ & $24.4 \%(40)$ \\
mbalance in oral flora & $50.6 \%(83)$ & $23.2 \%(38)$ & $26.2 \%(43)$ \\
\hline
\end{tabular}

Table (10) illustrated the dentists' opinion regarding denture adhesives from different points of view in which (93.3\%) agreement that ( Denture adhesives Increase the fitness $\{$ retention and stability \})which is near the result of Sloughter et al ${ }^{(9)}$ who stated that prosthodontists agreed with $100 \%$ consensus that denture adhesives were useful to provide additional retention and stability.

Also Table (10) showed that About $(88.4 \%)$ of dentists agreed that (Denture adhesives provide psychological comfort for patients) which agree with Adisman ${ }^{(24)}$ who stated that denture patients who have vocations of high public visibility such as attorneys, executives, actors, public speakers, and vocalists need and use denture adhesives for the security of a retentive denture. The avoidance of an embarrassing incident due to an unstable, loose fitting denture is a dominant consideration in their denture experience.

In Table (10) just (43.3\%) of dentists agreed that (Denture adhesives stabilize trial bases in early stages of dental fabrication) which revealed again poor knowledge of dentists about uses of these materials because poor retention of complete denture trail bases can interfere with jaw 
relation record - making and clinical evaluation of tooth arrangement, therefore conventional denture adhesive is often used to alleviate these problems ${ }^{(30)}$.

Table (10) illustrate the dentists' opinion regarding denture adhesives from different points of view

\begin{tabular}{|c|c|c|c|}
\hline Questions & Agree & Disagree & $\begin{array}{l}\text { No } \\
\text { opinion }\end{array}$ \\
\hline A Increase the fitness (retention and stability) & $93.3 \%(153)$ & $4.9 \%(8)$ & $8 \%(3)$ \\
\hline A Provide psychological comfort for patients & $88.4 \%(145)$ & $5.5 \%(9)$ & $6.1 \%(10)$ \\
\hline A Mask all underlying denture problems & $21.3 \%(35)$ & $64.1 \%(105)$ & $14.6 \%(24)$ \\
\hline A Contribute to avoiding dental visits & $53.1 \%(87)$ & $32.3 \%(53)$ & $14.6 \%(24)$ \\
\hline $\begin{array}{l}\text { A Stabilize trial bases in early stages of dental } \\
\text { brication }\end{array}$ & $43.3 \%(7$ & $30.5 \%(5$ & $26.2 \%(43)$ \\
\hline $\begin{array}{l}\text { A Augment retention, function and comfort } \\
\text { aring interim Period after insertion of new } \\
\text { enture. }\end{array}$ & & $11.6 \%$ & $20.7 \%(34)$ \\
\hline $\begin{array}{l}\text { A Provide additional retention and stability for } \\
\text { atients who have inadequate oral anatomy }\end{array}$ & $57.3 \%(94)$ & $28.7 \%(47)$ & $14 \%(23)$ \\
\hline $\begin{array}{l}\text { atient education on DA should be routine for all } \\
\text { enture patients. }\end{array}$ & $40.9 \%(67)$ & $45.1 \%(74)$ & $14 \%(23)$ \\
\hline $\begin{array}{l}\text { udents should be competent in management of } \\
\text { utine denture patient. }\end{array}$ & $61 \%(10$ & $17 \%(28)$ & $22 \%(36)$ \\
\hline $\begin{array}{l}\text { ducation on DA should be dea } \\
\text { Indergraduate curriculum in denta }\end{array}$ & $61 \%($ & $16.5 \%(27)$ & $22.5(37)$ \\
\hline
\end{tabular}

Sixty-one percent of dentist agreed that (Patient education on denture adhesives should be routine for all denture patients), and (Education on denture adhesives should be dealt in depth in Undergraduate curriculum in dental universities) which agree with Sloughter et al ${ }^{(9)}$ who demonstrated that only through education, for dentists and patients, would the dual goals of maximizing the beneficial aspects of denture adhesive use, while minimizing the misuse of denture adhesives be achieved.

\section{CONCLUSIONS}

The findings of the present study showed that dentist knowledge and attitude toward denture adhesive materials was moderate. Their information about denture adhesive indications, contraindications, advantages and disadvantages were very poor therefore prosthodontic specialist in Collage of Dentistry, University of Mosul should insist on denture adhesive in student curriculum with increasing the credit hours.

\section{REFERENCES}

1. Tarbet W J, and Boone M, Schmidt NF. Effect of a denture adhesive on complete denture dislodgment during mastication. J Prosthet Dent, 1980;44:374 -378

2. Chew CL, Boone ME, Swartz ML, Philips RW.Denture adhesives: their effects on denture retention and stability. $J$ Dent, $1985 ; 13(2): 152-159$.

3. Özcan M, Kulak Y, de Baat C, Arikan A, Ucankale M. The effect of a new denture adhesive on bite force until denture dislodgement. J Prosthodon,2005;14(2):122 -126. 


\section{Hatim NA, Ali HK,Shindala HM}

4. De Beet C, van't Hof M, van Zeghbroeck L, Özcan M, Kalk W.An international multicenter study on the effectiveness of a denture adhesive in maxillary dentures using disposable gnathometers. Clin Oral Inves, 2007;11(3):237-243

5. Ali HKh. Evaluation of Retentive Ability of Modified Denture Adhesive Materials. M.Sc. Thesis, College of Dentistry, University of Mosul. 2008

6. Zarb GA., Bolender C.L., Eckert S., Fenton A.H.: Prosthodontic treatment for edentulous patients. $12^{\text {th }}$ edition. Chapter 22. Mosby, Inc.2004; Pp. 437 - 448.

7. Grasso JE.Denture adhesives: changing attitudes. J Am Dent Assoc,1996;127:90-96.

8. Roessler DM: Complete denture success for patients and dentists. Int Dent J,2003;53(5):340-345.

9. Slaughter A, Katz RV, Grasso JE. Professional attitudes toward denture adhesives: A Delphi technique survey of academic prosthodontics. J Prosthe. Dent,1999;82(1):80-89.

10. Coates AJ.Usage of denture adhesives. J Dent,2000;28:137-140.

11. Özcan M, Kulak Y, Arikan A, Silahtar E. The attitude of complete denture wearers towards denture adhesives in Istanbul. J Oral Rehabil.2004;31:131-134.

12. Koksal T, Dikbas I, Ozkurt Z, Bal B, Kazaoglu E. A survey of dentists attitude toward denture adhesives. OHDMBSC Martie,2007;6(1):33-39.

13. Fakhri H, Fayaz F, Faramarzi F, Javaheri H.The knowledge and attitude of general dentist towered denture adhesive in Tehran Ind. J Dent Res,2008;20(2)164-168.

14. Karlsson S, and Swartz B. Effect of a denture adhesive on mandibular denture dislodgment. Quintessence Int, 1990;21:625-627.

15. Berg E.A clinical comparison of four denture adhesives. Int J Prosthodont,1991;4(5):449-456.

16. Ghani F, Picton DCA, Likeman PR.Some factors affecting retention forces with the use of denture fixatives. Br Dent $J, 1991 ; 171: 15-19$.

17. Ghani F, Picton D. Some clinical investigations on retention forces of maxillary complete dentures with the use of denture fixatives. J Oral Rehabil,1994;21:631-640.

18. Grasso JE, Gay T, Rendell J. Effect of denture adhesive on retention of the mandibular and maxillary dentures during function. J Clin Dent,2000;11(4):98-103.

19. Hatim NA, and Taqa AAR.Newly fabricated Iraqi denture adhesive materials. Jordan Dent J,2001;16(1\&2):135142.

20. Salman YM. Effect of denture adhesives on the retention of maxillary complete denture. M.Sc. Thesis, College of Dentistry, University of Baghdad 2001.

21. British Pharmaceutical Codex. Part I. The Pharmaceutical Press. Great Britain. London, Branford 1963.

22. Stafford GD. Denture adhesives a review of their uses and compositions. Dent Practit,1970; 21(1):17-19.

23. Polyzois GL. An update on denture fixatives. Dent Update,1983;10:579-583.

24. Adisman IK. The use of denture adhesives as an aid to denture treatment. J Prosthet Dent,1989;62:711-715.

25. Jagger DC, and Harrison A. Denture fixatives an update for general dental practice. Brit Dent J,1996;180(8):311313

26. Grasso JE. Denture adhesives. Dent Clin North Am,2004;48:721-733.

27. Psillakis JJ. Denture adhesives usage in removable prosthodontics. Dent Today,2003;3:90-93.

28. Yadav A, Yadav S. Denture adhesives their stand in prosthodontics. J Indian Prosthodon Soc,2005;5(2):62-64.

29. Donahue TJ. Denture adhesive. J Am Dent Assoc, 1981;102:154.

30. Stevenson RB. Toothpaste used as short acting denture adhesive. J Prosthet Dent, 1995;74: 119. 